\title{
Riječka Cochrane grupa - prikaz aktivnosti i rezultata
}

\section{Cochrane group from Rijeka - review of activities and results}

\author{
Goran Poropat ${ }^{*}$, Vanja Giljača, Goran Hauser, Davor Štimac
}

Zavod za gastroenterologiju, Klinika za internu medicinu, Klinički bolnički centar Rijeka, Rijeka
Sažetak. Dugogodišnja suradnja riječkih gastroenterologa sa specifičnim grupama u sklopu Cochrane kolaboracije rezultirala je značajnim napretkom na polju znanstveno-istraživačke djelatnosti i brojnim publikacijama. Spoznaje i zaključci dosegnuti u sustavnim pregledima Cochrane predstavljaju pouzdane stručne dokaze u raznim područjima gastroenterologije, posebno kronične hepatitis $\mathrm{C}$ infekcije, kolestatskih bolesti jetre $\mathrm{i}$ akutnog pankreatitisa. Navedene publikacije visoko su citirani radovi, koji su implementirani i u nekim međunarodnim smjernicama, odnosno preporukama liječenja. Doprinosom riječke Cochrane grupe otvorena su vrata suradnje s brojnim inozemnim stručnjacima i suradnicima, pokrenuto je organiziranje tečajeva medicine temeljene na dokazima i unaprijeđena je suradnja s Hrvatskim Cochrane centrom te drugim domaćim znanstvenicima. Ovaj pregledni članak predstavlja pregled dosadašnjih postignuća riječkih autora u sklopu Cochrane kolaboracije uz sažet prikaz najznačajnijih rezultata i zaključaka u objavljenim Cochrane sustavnim pregledima s ciljem upoznavanja javnosti s mogućnostima rada u Cochrane kolaboraciji i vrstom znanstveno-istraživačke djelatnosti koja se u njenom okrilju provodi te promocije i popularizacije medicine temeljene na dokazima u široj znanstvenoj i stručnoj zajednici.

Ključne riječi: Cochrane kolaboracija; medicina temeljena na dokazima; metaanaliza; sustavni pregled

Abstract. The long-term cooperation of gastroenterologists from Rijeka with specific groups within the Cochrane Collaboration has achieved a significant progress in the field of scientific research and numerous publications. The findings and conclusions reached in the published Cochrane systematic reviews represent reliable evidence in various gastroenterology fields, particularly chronic hepatitis $\mathrm{C}$ infection, cholestatic liver disease and acute pancreatitis. The mentioned publications are highly quoted papers, which are cited in different international guidelines and treatment recommendations. The contribution of authors from Rijeka, started a cooperation with several foreign experts and associates. Courses in evidence-based medicine have been organized, and the collaboration with the Croatian Cochrane Center and other Croatian scientists has been enhanced. This review article presents an overiew of the achievements of authors from Rijeka within the Cochrane Collaboration with a summary of the most important results and conclusions from the systematic reviews aiming to inform the public about the opportunities given by the Cochrane Collaboration and the type of scientific research implemented by it, as well as, to promote and popularize evidence-based medicine in a broad scientific and professional community.

Key words: Cochrane Collaboration; evidence-based medicine; meta-analysis; systematic review 


\section{UVOD}

Aktivnosti liječnika i znanstvenika Klinike za internu medicinu KBC-a Rijeka na području medicine temeljene na dokazima započele su tijekom 2006. godine postepenim uspostavljanjem suradnje $\mathrm{s}$ Cochrane hepatobilijarnom grupom u Kopenhagenu, Danska. Predvođeni tadašnjim predstojnikom Zavoda za gastroenterologiju, prof. dr. sc. Davorom Štimcem, većinom riječki gastroenterolozi, a manjim dijelom opći internisti, započeli su svoj put i rad, dulji od desetljeća, u sklopu Cochrane kolaboracije, koji je i danas prisutan i produktivan. Edukacijskim boravcima djelatnika Klinike za internu medicinu u središtu hepatobilijarne grupe i Cochrane Trial Unitu u Kopenhagenu, pod vodstvom prof. Christiana Gluuda, ostvareni su uvjeti za samostalan rad istraživačke grupe, provođenje daljnje edukacije u vidu tečajeva medicine temeljene na dokazima u Rijeci, popularizacije navedenog koncepta znanstveno-istraživačke djelatnosti i uključivanja novih članova u našu istraživačku grupu uz uspostavljanje suradnje $s$ istraživačima iz drugih institucija, uključujući i inozemne (slika 1).

Riječka grupa povezuje se s radom Hrvatskog Cochrane centra u Splitu te postaje njegova sastavnica uz aktivno sudjelovanje u svrhu promocije medicine temeljene na dokazima u Hrvatskoj. Važna suradnja uspostavlja se s istraživačima i djelatnicima Klinike za gastroenterologiju Kliničkog centra Srbije u Beogradu te Klinike za gastroenterologiju sa Sveučilišta u Nišu. Daljnje aktivnosti unutar Cochrane kolaboracije vremenom se šire i izvan hepatobilijarne grupe, uključivanjem u aktivnosti Cochrane grupe za bolesti gornjeg dijela probavnog sustava i gušterače sa sjedištem u Hamiltonu, Kanada, a prvenstveno na području akutnog pankreatitisa. Evolucijom Cochrane kolaboracije tijekom posljednjih nekoliko godina, osim rezultata na području sustavnih pregleda intervencija, među prvima se uključujemo i postižemo zavidne rezultate na području sustavnih pregleda dijagnostičkih metoda. Otvaranjem ovog poglavlja naš se rad povezuje i s autorima iz Velike Britanije, koji usko surađuju s hepatobilijarnom grupom Cochrane.

Navedenim kolaboracijama postignut je značajan doprinos na polju sustavnih preglednih radova $\mathrm{i}$ metaanaliza liječenja kronične infekcije virusom hepatitisa C (HCV), kao i na području liječenja kroničnih kolestatskih bolesti jetre, u prvom redu primarne bilijarne ciroze i primarnog sklerozirajućeg kolangitisa, dok je enteralna nutricija kao terapijski postupak bio tema u području akutnog pankreatitisa. Dijagnostički sustavni pregledi obuhvatili su kompletnu dijagnostiku koledokolitijaze, uspoređujući dijagnostičke točnosti i karakteristike specifičnih laboratorijskih nalaza, neinvazivnih slikovnih metoda do invazivnih kirurških dijagnostičkih postupaka.

Sustavni pregledi Cochrane potječu od autora, orijentirani su k autorima i istovremeno podložni kritičkoj recenziji međunarodnih stručnjaka i javnosti općenito.

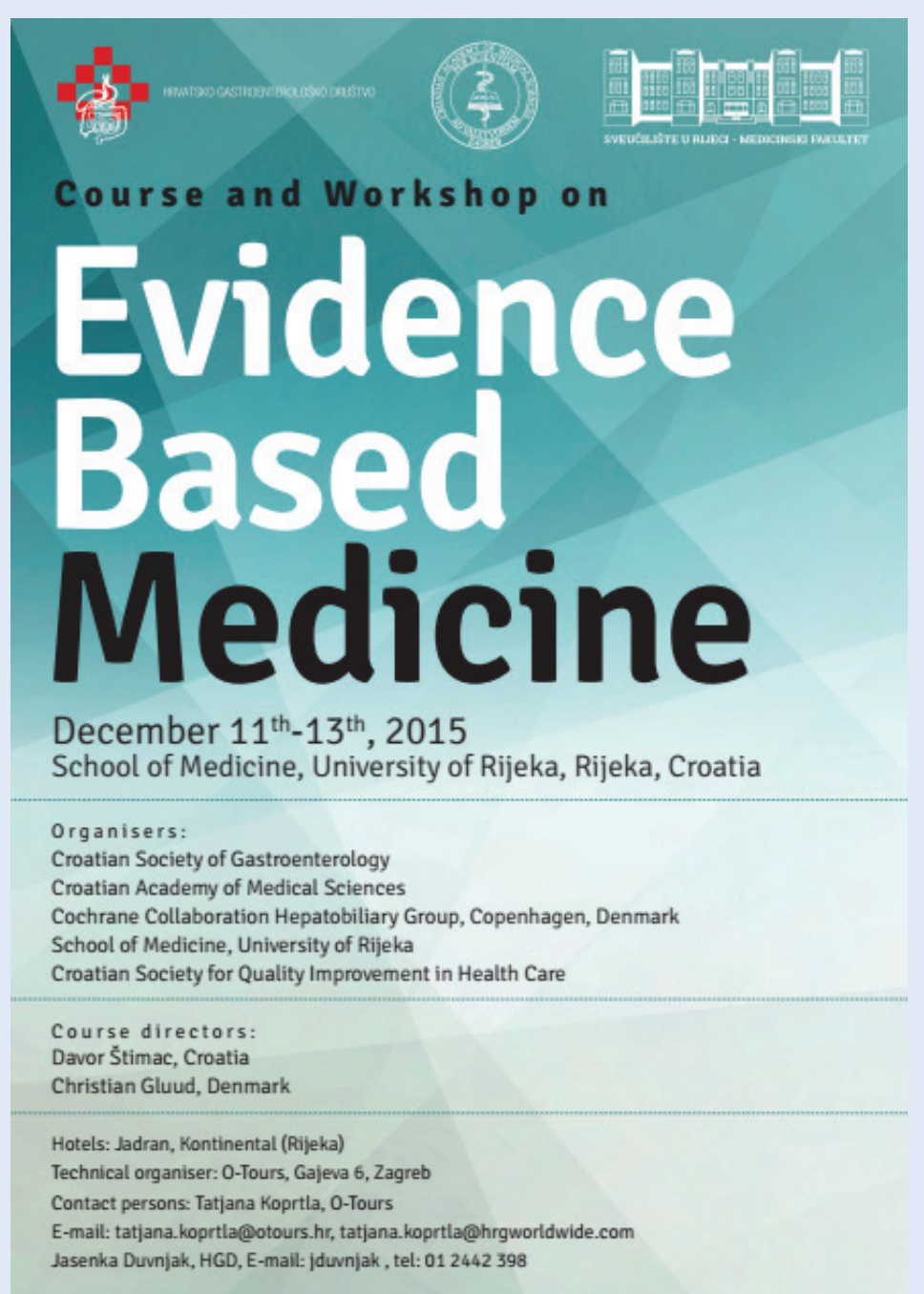

Slika 1. Naslovnica programa tečaja Evidence Based Medicine održanog u Rijeci 2015. godine. 
Svrha ovog pregleda je prikazati znanstvenoj, stručnoj i široj javnosti dosadašnje aktivnosti i dostignuća riječke grupe autora u sklopu Cochrane kolaboracije na svjetskoj razini, pružiti uvid u mogućnosti koje pruža suradnja s Cochrane kolaboracijom na polju znanstveno-istraživačke djelatnosti te predstaviti buduće planove i otvoriti vrata novim suradnicima u znanstvenom radu na najvišoj znanstvenoj metodološkoj razini.

\section{KRONIČNI HEPATITIS C}

Kronična infekcija virusom hepatitisa C predstavlja jedan od najčešćih i najznačajnijih uzroka kronične bolesti jetre i njenih komplikacija. Procjenjuje se da više od 180 milijuna ljudi boluje od navedene infekcije, iako je većina oboljelih asimptomatična i nesvjesna vlastite bolesti ${ }^{1}$. Tijekom posljednjih nekoliko godina u tijeku je intenzivan razvoj novih direktnih antivirusnih lijekova (DAA) koji predstavljaju pravu revoluciju u liječenju kroničnog hepatitisa $\mathrm{C}$ i čija uspješnost nerijetko premašuje $95 \%^{2}$. No, eri direktnih antivirusnih lijekova prethodila je dugogodišnja primjena kombinacije pegiliranog interferona-alfa (PegIFN- $\alpha$ ) i ribavirina (RBV). Navedena je kombinacija lijekova predstavljala prvi važniji terapijski korak unaprijed, a iako često praćena brojnim i različito teškim nuspojavama, ovaj pristup rezultirao je značajnim brojem izliječenih pacijenata. Cilj liječenja kronične hepatitis C infekcije predstavlja spriječavanje razvoja komplikacija postizanjem eradikacije virusa. Eradikacija predstavlja postizanje trajnog virološkog odgovora (engl. Sustained Virological Response; SVR) te se definira kao nedetektibilnost virusnog RNA 12, odnosno 24 tjedana nakon završetka terapije.

\section{Pegilirani interferon i ribavirin}

Primjena interferona započela je u vidu monoterapije klasičnim interferonom- $\alpha$, koja je potom obogaćena dodatnom primjenom ribavirina. Interferon djeluje posredstvom kompleksnih unutarstaničnih mehanizama utječući prije svega ne ekspresiju specifičnih gena, kojima se stvaraju antivirusni uvjeti u stanici, dok manje utječe na samu virusnu replikaciju. Procesom pegilacije, odnosno vezanja polietilen-glikola na molekulu interferona formiran je pegilirani interferon, koji je značajno povećana biodostupnost lijeka, a time i njegova učinkovitost. Primjenom navedene kombinacije PegIFN- $\alpha$ i RBV-a djelotvornost terapija povećana je na otprilike $45 \%$ za genotip 1 i $80 \%$ za genotip 2 i $3^{3,4}$.

U sustavnom pregledu koji je objavljen 2014. godine provedena je usporedba primjene PegIFN- $\alpha$ $\mathrm{u}$ odnosu na klasični interferon- $\alpha \mathrm{u}$ kombinaciji $\mathrm{s}$ RBV-om u liječenju kronične hepatitis $C$ infekcije. Obuhvaćena su isključivo randomizirana klinička istraživanja (engl. Randomized Clinical Trial; RCT) koja istražuju navedene intervencije u pacijenata s kroničnim hepatitisom $C$, neovisno o statusu publikacije, jeziku i/ili vremenu publikacije. Primarni ishodi istraživanja definirani su kao mortalitet, morbiditet povezan $s$ jetrom, nuspojave i kvaliteta života, dok je SVR naveden kao sekundarni ishod. Pretraga literature obuhvatila je šest različitih elektronskih baza podataka i rezultirala s ukupno 8089 referenci. Izbacivanje duplikata i jasno irelevantnih referenci te studija koje nisu zadovoljavale uključne kriterije pregledom je ukupno obuhvatilo 27 randomiziranih kliničkih istraživanja s 5938 ispitanika. Usporedbom dviju intervencija nije utvrđena značajna razlika u utjecaju na mortalitet i morbiditet povezan s jetrom. Većina je nuspojava bila podjednako zastupljena u obje grupe pacijenata, ali pojedine su, poput neutropenije, trombocitopenije, artralgija, mučnine i reakcija na mjestu primjene lijeka, bile češće prisutne u liječenih pegiliranim oblikom. No primjenom PegIFN- $\alpha$ SVR je postignut u značajno većeg broja pacijenata, uz relativni rizik (RR) 1,39 i $95 \%$ interval pouzdanosti (engl. confidence interval; $\mathrm{Cl}$ ) od 1,25 do 1,56 (slika 2$)^{5}$.

$\mathrm{U}$ drugom sustavnom pregledu objavljenom iste godine uspoređivane su učinkovitosti dviju vrsta PegIFN- $\alpha$, odnosno PegIFN- $\alpha$ 2a i 2 b. Ponovno su obuhvaćeni isključivo RCT-i koji uspoređuju navedene vrste interferona neovisno o pratećim intervencijama u liječenju kroničnog hepatitisa $\mathrm{C}$. Korišteni su jednaki primarni i sekundarni ishodi kao u prethodno spomenutom sustavnom pregledu. Sistematskim pretraživanjem šest elektroničkih baza podataka evidentirano je 6638 referenci, od kojih je naposljetku u analizu uključeno 17 RCT-a s ukupno 5.847 randomiziranih ispitanika. Rezultati metaanalize nisu potvrdili 


\begin{tabular}{|c|c|c|c|c|c|}
\hline Study or subgroup & $\begin{array}{r}\text { PEG INF+RBV } \\
n / N\end{array}$ & $\begin{array}{r}\text { INF+RBN } \\
\mathrm{NN}\end{array}$ & $\begin{array}{c}\text { Risk Ratio } \\
M- \\
\text { HRandom,95\% } \\
Q\end{array}$ & Weight & $\begin{array}{c}\text { Risk Ratio } \\
\text { M- } \\
\text { HRandomgs\% } \\
\mathrm{Cl}\end{array}$ \\
\hline Alfaleh 2004 & $21 / 48$ & $14 / 48$ & $\longrightarrow$ & $27 \%$ & $1.50[0.87,259]$ \\
\hline Bruno 2004 & $67 / 163$ & $44 / 48$ & - & $49 \%$ & $1.38[1.02,1.88]$ \\
\hline Cantit 2002 & $41 / 60$ & $17 / 57$ & - & $3.6 \%$ & $2.29[1.48,3.54]$ \\
\hline Dertala 2005 & $10 / 35$ & $8 / 35$ & & $1.6 \%$ & $1.25[0.56 .279]$ \\
\hline Derbala 2006 & $25 / 40$ & $9 / 40$ & $\longrightarrow$ & $23 \%$ & $278[1.49,5.18]$ \\
\hline Dollinger 2005 & $S / 22$ & $4 / 18$ & & $0.8 \%$ & $1.02[0.32 .3 .26]$ \\
\hline Esenxt 2003 & $45 / 100$ & $39 / 100$ & - & $4.6 \%$ & $1.18[0.85,1.65]$ \\
\hline Fargion 2004 & $22 / 92$ & $18 / 93$ & - & $27 \%$ & $1.24[0.71 .215]$ \\
\hline Fried 2002 & $255 / 453$ & $197 / 444$ & - & $7.0 \%$ & $1.27[1,11,1,45]$ \\
\hline Hinrichsen 2002 & $24 / 36$ & $22 / 36$ & - & $4.4 \%$ & $1.09[0.77,1.55]$ \\
\hline Horsmans 2008 & $51 / 98$ & $73 / 160$ & - & $55 \%$ & $1.14[0.88,1.47]$ \\
\hline Inumi 2004 & $10 / 23$ & $8 / 26$ & & $1.8 \%$ & $1.41[0.67,297]$ \\
\hline Lee 2005 & $51 / 76$ & $49 / 77$ & r & $5.8 \%$ & $1.05[0.84,1.33]$ \\
\hline Mangia 2005 & $79 / 121$ & $40 / 120$ & - & $5.2 \%$ & $1.96[1.47,260]$ \\
\hline Mams 2001 & 5181025 & $235 / 505$ & - & $7.2 \%$ & $1.09[0.97,1.21]$ \\
\hline Nupoli 2005 & $21 / 32$ & $12 / 32$ & & $30 \%$ & $1.75[1.05,292]$ \\
\hline Nevens 2010 & $120 / 230$ & 58213 & - & $5.6 \%$ & $1.92[1.49 .247]$ \\
\hline PRETTY 2005 & $19 / 89$ & $13 / 89$ & - & $22 \%$ & $1,46[0.77 .278]$ \\
\hline Rahman 2007a & 621156 & $51 / 154$ & -- & $5.0 \%$ & $1.20[0.89,1.61]$ \\
\hline Rahman 2007b & 88132 & $85 / 130$ & 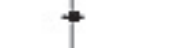 & $65 \%$ & $1.02[0.86,1.21]$ \\
\hline Roffi 2008 & $25 / 57$ & $12 / 36$ & & $27 \%$ & $1.32[0.76,2.27]$ \\
\hline Scotto 2005 & $13 / 26$ & $19 / 52$ & & $29 \%$ & $1.37[0.81 .231]$ \\
\hline Shobokelhi 2003 & $30 / 60$ & $18 / 60$ & & $33 \%$ & $1.67[1.05,2.65]$ \\
\hline Sjogren 2007 & $12 / 29$ & $11 / 30$ & & $2.2 \%$ & $1.13[0.60 .214]$ \\
\hline Thakeb 2003 & $35 / 31$ & $8 / 49$ & & $21 \%$ & $4.20[2.17,8.14]$ \\
\hline Tobobta 2005 & $12 / 28$ & $8 / 20$ & & $20 \%$ & $1.07[0.54 .2 .13]$ \\
\hline Weal 2006 & $12 / 18$ & $10 / 32$ & & $24 \%$ & $2.13[1.16,3.92]$ \\
\hline Total $(95 \% \mathrm{CI})$ & 3300 & 2804 & • & $100.0 \%$ & $1.39[1.25,1.56]$ \\
\hline \multicolumn{6}{|c|}{ Total events: 1673 (PEG INF+REV), 1081 (INF+REV) } \\
\hline \multicolumn{6}{|c|}{ Heterogencity: Tsu2 $=0.04 ; 0 i^{2}=71.53$, df $=26(P<0.00001) ; p^{2}=64 \%$} \\
\hline \multicolumn{6}{|c|}{ Test for overall effect: $Z=5.20$ ( $P<0.00001)$} \\
\hline \multicolumn{6}{|c|}{ Test for subgroup differences: Not applicable } \\
\hline
\end{tabular}

Slika 2. Usporedba primjene PegIFN- $\alpha$ i RBV-a u odnosu na nepegilirani interferon- $\alpha$ i RBV. Ishod: SVR (preuzeto uz dopuštenje iz ref. 5)

značajnu razliku u mortalitetu i morbiditetu povezanim s jetrom između pacijenata liječenih PegIFN- $\alpha 2 a$ i pacijenata liječenih PegIFN- $\alpha 2 b$. Analizom učestalosti nuspojava i kvalitete života liječenih pacijenata također nije utvrđena značajna razlika. Temeljem metaanalize 12 studija koje su prikazale podatak o SVR-u s ukupno 5013 ispitanika, uspješnost postizanja SVR-a bila je značaj- 
no veća u pacijenata liječenih PegIFN- $\alpha$ 2a u odnosu na pacijente liječene PegIFN- $\alpha$ 2b (RR 1,12; $95 \% \mathrm{Cl} 1,06$ do 1,18) (slika 3) ${ }^{6}$.

Rezultati ovih sustavnih pregleda potvrdili su značajnu prednost PegIFN- $\alpha$ u odnosu na klasični interferon $u$ liječenju pacijenata $s$ kroničnim hepatitisom C. No rezultati također ukazuju na činjenicu da pojedina provedena klinička istraživanja uglavnom ne procjenjuju klinički važne

Publikacije Cochrane kolaboracije su visokocitirani radovi čiji su rezultati implementirani u međunarodnim smjernicama, odnosno dijagnostičko-terapijskim preporukama.

Osim rezultata na području sustavnih pregleda intervencija, riječka grupa autora među prvima se uključuje i postiže zavidne rezultate na području sustavnih pregleda dijagnostičkih metoda. ishode, poput mortaliteta i morbiditeta kao primarne ishode ili uopće, stoga nema dovoljno dostupnih dokaza kojim se mogao potvrditi ili opovrgnuti učinak PegIFN- $\alpha$ ili klasičnog interferona na navedene ishode. lako su u stručnoj javnosti i od strane farmaceutskih tvrtki pojedini oblici PegIFN- $\alpha$ predstavljani kao jednako učinkoviti, naš sustavni pregledni rad ukazuje da dostupni dokazi upućuju na veću učinkovitost PegIFN- $\alpha$ 2a u postizanju SVR-a. Ovaj vrlo zanimljiv i neočekivani rezultat dodatno je potvrđen i tzv. sekvencijskom analizom studija (engl. Trial Sequential Analysis; TSA), metodom procjene potrebne veličine uzorka u metaanalizama kojim se nastoji utvrditi mogućnost slučajne pogreške, odnosno pogreške tip 1 u donošenju zaključaka temeljem rezultata metaanalize. Navedenom analizom potvrđeno je da je zaključak o prednosti PegIFN- $\alpha$ $2 a$ donesen na temelju dovoljnog broja uključenih pacijenata uz pouzdanu razinu statističke značajnosti.

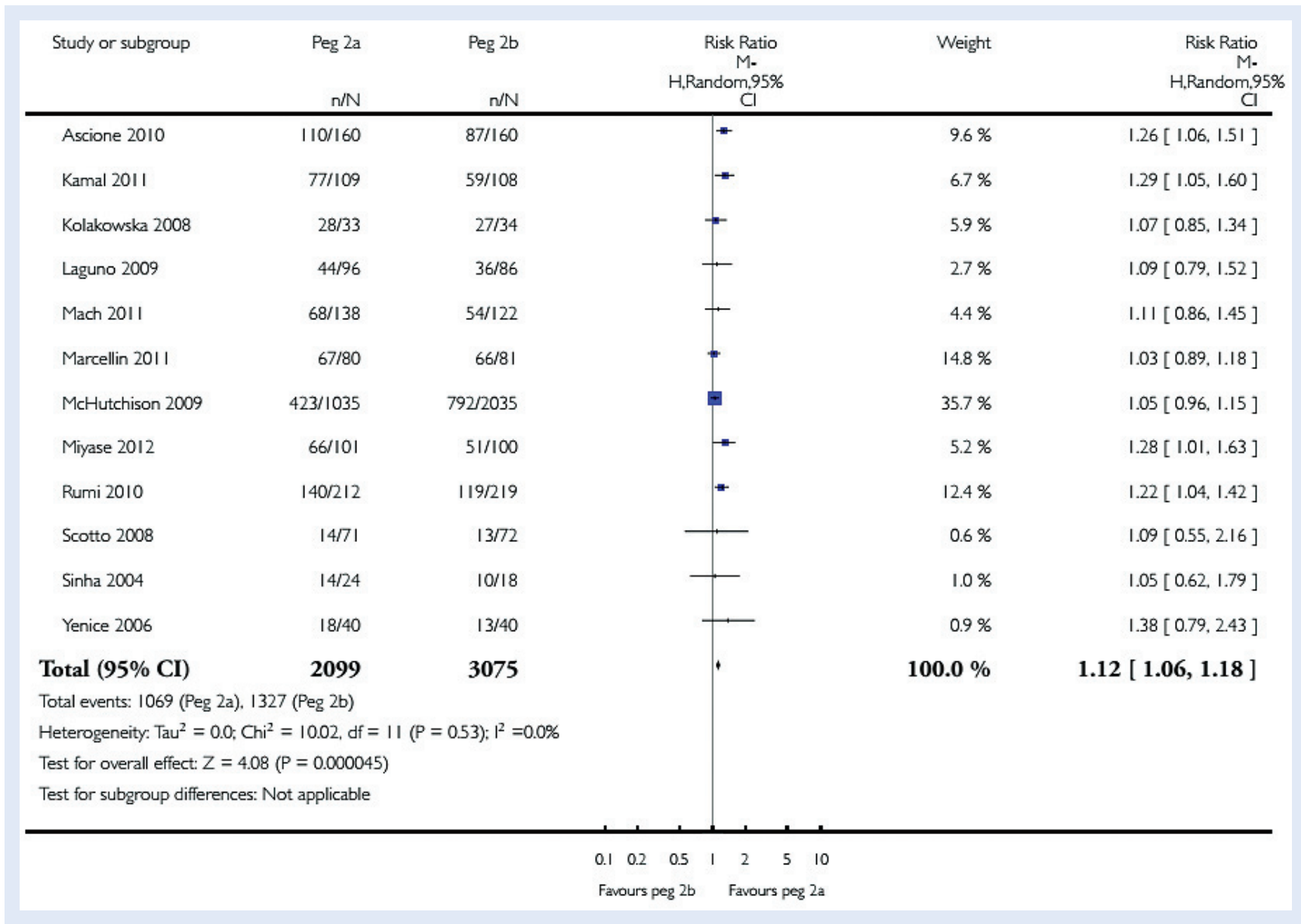

Slika 3. Usporedba primjene PegIFN- $\alpha$ 2a i PegIFN- $\alpha$ 2b u liječenju kroničnog hepatitisa C. Ishod: SVR (preuzeto uz dopuštenje iz ref. 6) 


\section{Direktni antivirusni lijekovi ${ }^{7}$}

Cochrane sustavni pregled primjene direktnih antivirusnih lijekova u liječenju kroničnog hepatitisa C predstavlja zajednički recentan rad koji je u trenutku pisanja ovog preglednog članka u postupku publikacije. Plod je suradnje više autora iz različitih europskih zemalja pod okriljem Cochrane hepatobilijarne grupe u koji su uključeni i članovi naše Cochrane grupe. Direktni antivirusni lijekovi glavni su predstavnici europskih i svjetskih smjernica liječenja kroničnog hepatitisa C tijekom posljednjih nekoliko godina. Riječ je o lijekovima koji djeluju primarno na različite nestrukturne virusne proteine izravno inhibirajući ili onemogućavajući virusnu replikaciju. DAA se s obzirom na mehanizam djelovanja mogu podijeliti u četiri skupine: inhibitori NS3/4A proteaze, nukleozidni/ nukleotidni inhibitori, nenukleozidni inhibitori virusne RNA polimeraze i inhibitori NS5A proteaze. Cilj ovog sustavnog pregleda Cochrane bio je utvrditi potencijalnu učinkovitost i eventualnu štetnost primjene DAA-a u oboljelih od kronične hepatitis C infekcije. Obuhvaćena su randomizirana klinička istraživanja u koja su uključeni odrasli pacijenti, neovisno o duljini trajanja bolesti, komorbiditetima i statusu prethodnog liječenja osnovne bolesti. Provedena je usporedba primjene bilo koje vrste DAA-a u monoterapiji ili kombiniranoj primjeni, a neovisno o eventualnoj pratećoj terapiji u odnosu s placebom, izostankom intervencije ili drugom antivirusnom intervencijom, osim DAA-a. Kao primarni ishodi definirani su morbiditet povezan $\mathrm{s}$ hepatitisom C ili HCV-povezani sveukupni mortalitet, postotak pacijenata sa zabilježenom jednom ili više teških nuspojava te kvaliteta života. U sekundarne ishode uključeni su mortalitet, postotak pacijenata s ascitesom, varicealnim krvarenjem, hepatorenalnim sindromom, hepatocelularnim karcinomom, hepatalnom encefalopatijom, blagim i umjerenim nuspojavama te postotak pacijenata koji je postigao SVR.

Sustavnim pretraživanjem obuhvaćeno je čak jedanaest baza podataka, uključujući neke od kineskih baza s obzirom na učestalost navedene patologije u Jugoistočnoj Aziji. Identificirano je 9.358 potencijalno relevantnih referenca, od čega je u analizu uključeno ukupno 138 studija s ukupno 25.232 ispitanika. Od navedenog broja 84 studije s 13.466 ispitanika obuhvaćale su primjenu DAA-a koji su dostupni na tržištu ili su u procesu razvoja. Dostupnost podataka o definiranim kliničkim ishodima bila je u uključenim studijama prilično ograničena te za većinu kliničkih ishoda nema dovoljno dokaza kojima bi potvrdili ili odbacili ikakav relevantan učinak na klinički važne ishode. Utvrđeno je da primjena DAA-a ne utječe značajno na pojavnost teških nuspojava, ali provedbom TSA-a utvrđeno je da za sada nije uključen dovoljan broj ispitanika kako bi se sa sigurnošću potvrdili navedeni rezulta-

Rad u Cochrane kolaboraciji omogućava sudjelovanje u produkciji znanstvenih radova najviše metodološke razine. Cochrane kolaboracija omogućava upoznavanje, suradnju i zajednički rad s nekim od najvećih stručnjaka s područja znanstvene metodologije, biostatistike, ali i specifičnih medicinskih područja.

ti u kontekstu metaanalize. Većina uključenih studija rezultate je izrazila u vidu prikaza udjela pacijenata s postignutim SVR-om, iako on predstavlja za sada nevalidirani surogatni ishod. Analizom SVR-a utvrđeno je da primjena DAA-a u odnosu na placebo, izostanak intervencije ili neku drugu anti-HCV intervenciju značajno povećava udio pacijenata sa SVR-om (tablica 1).

Temeljem provedene analize većina studija primjene DAA-a u kroničnom hepatitisu $C$ kao primarni ishod koristi SVR, koji unatoč tome što se smatra osnovnim parametrom u regulaciji provedbe terapije i procjene uspješnosti liječenja, predstavlja nevalidirani surogatni ishod. Studije su uglavnom bile pod visokim rizikom sustavne pogreške, u prvom redu zbog značajnog utjecaja farmaceutskih tvrtki u njihovu financiranju. Praćenje pacijenata u studijama prilično je kratko, do 38 tjedana po završetku liječenja, što onemogućava stjecanje uvida u relevantne kliničke ishode tijekom duljeg razdoblja. Stoga su potrebni dodatni dokazi dugoročne učinkovitosti DAA-a na klinički važne ishode, kao što su smrtnost i HCVpovezani morbiditet.

\section{KOLESTATSKE BOLESTI JETRE}

Kolestatske bolesti jetre predstavljaju skupinu kroničnih upalnih bolesti jetre, koje su često ne- 
Tablica 1. Usporedba direktnih antivirusnih lijekova i kontrole (placebo, izostanak intervencije ili druga intervencija, osim DAA-a) (prilagođeno prema ref. 7)

\begin{tabular}{|c|c|c|c|c|c|}
\hline \multirow{2}{*}{ Ishodi } & \multicolumn{2}{|c|}{ Predviđeni apsolutni učinak (95 \% Cl) } & \multirow{2}{*}{$\begin{array}{c}\text { Relativni učinak (95 \% CI) } \\
\text { (TSA-prilagođen } \mathrm{CI} \text { ) }\end{array}$} & \multirow{2}{*}{$\begin{array}{c}\text { Broj ispitanika } \\
\text { (broj studija) }\end{array}$} & \multirow{2}{*}{ Kvaliteta dokaza } \\
\hline & Rizik (kontrola) & Rizik (DAA) & & & \\
\hline $\begin{array}{l}\text { Sveukupna } \\
\text { smrtnost }\end{array}$ & $2 / 1000$ & $\begin{array}{l}7 / 1000 \\
(1 \text { do } 42)\end{array}$ & $\begin{array}{l}\text { OR } 3,72 \\
(0,53 \text { do } 26,18)\end{array}$ & $2996(11)$ & Jako niska \\
\hline $\begin{array}{l}\text { Udio pacijenata s } \\
\text { teškim } \\
\text { nuspojavama }\end{array}$ & $56 / 1000$ & $\begin{array}{l}52 / 1000 \\
(49 \text { do } 55)\end{array}$ & $\begin{array}{l}\text { OR } 0,93 \\
(0,88 \text { do } 0,99) \\
\text { (TSA CI } 0,71 \text { do } 1,33 \text { ) }\end{array}$ & $15817(43)$ & Jako niska \\
\hline $\begin{array}{l}\text { Udio pacijenata sa } \\
\text { SVR-om }\end{array}$ & $541 / 1000$ & $\begin{array}{c}238 / 1000 \\
(200 \text { do } 281)\end{array}$ & $\begin{array}{l}\text { RR } 0,44 \\
(0,37 \text { do } 0,52) \\
\text { (TSA CI } 0,42 \text { do } 0,55 \text { ) }\end{array}$ & $6886(31)$ & Jako niska \\
\hline
\end{tabular}

poznate etiologije, a koje su karakterizirane zahvaćenošću i patološkim promjenama na intra-i/ ili ekstrahepatičnim žučnim vodovima. Osnovna karakteristika je razvoj kolestaze, odnosno poremećaja normalnog protoka žuči. Kolestaza može biti primarna i sekundarna. Primarne kolestatske bolesti posljedica su bolesti samih žučnih vodova, dok je sekundarna kolestaza posljedica najčešće žučnih kamenaca ili novotvorina bilijarno-pankreatičnog sustava. Najčešće i najznačajnije bolesti koje ubrajamo u primarne kolestatske bolesti jetre su primarni bilijarni kolangitis, nekad poznatiji kao primarna bilijarna ciroza (PBC) i primarni sklerozirajući kolangitis (PSC). U osnovi su to kronične autoimune bolesti jetre, koje su tijekom duljeg vremenskog razdoblja potpuno asimptomatične i otkrivaju se najčešće slučajnim utvrđivanjem alteriranih kolestatskih laboratorijskih parametara. No, progresivnog su tijeka i vode u razvoj ciroze jetre i kronično zatajenje jetre. Jedina do danas učinkovita terapijska opcija je transplantacija jetre. Medikamentozna terapija primjenjuje se prvenstveno sa svrhom usporavanja progresije bolesti i odgode transplantacijskog liječenja. U ovu kategoriju svrstavamo i autoimuni hepatitis $(A I H)$, kroničnu upalnu bolest jetre vrlo varijabilne kliničke prezentacije. Za razliku od prethodno spomenutih, u AlH-u postoje medikamentozne opcije kojima se postižu bolji rezultati i u određenih pacijenata adekvatna kontrola bolesti. Ove se bolesti ponekad mogu javljati zajedno, odnosno pacijenti mogu iskazivati pojedine karakteristike dviju različitih bolesti. $U$ tom slučaju govorimo o tzv. sindromima preklapanja (engl. overlap syndromes).

\section{Primarna bilijarna ciroza-10}

Riječka Cochrane grupa publicirala je ukupno tri Cochrane sustavna pregleda, od kojih neka samostalno, a neka u suradnji sa suradnicima iz Srbije. Jedan od prvih radova odnosi se na primjenu metotreksata u liječenju pacijenata s PBC-om. Metotreksat je lijek koji djeluje kao antagonist folne kiseline te značajno inhibira stanično posredovanu imunost i ostvaruje imunosupresivni učinak. Metotreksat se pokušalo koristiti kao monoterapiju u liječenju PBC-a s obzirom na to da je utvrđen povoljan učinak na upalnu zahvaćenost hepatocita i žučnih vodova. Nije, međutim, utvrđen povoljan učinak na fibrozu i histološki stadij bolesti. Primjena metotreksata u kombinaciji sa standardom liječenja, odnosno urosdeoksikolnom kiselinom (UDCA) nije pokazala značajnih poboljšanja u kliničkom tijeku i prognozi oboljelih od PBC-a. Zbog navedenog, cilj ovog sustavnog pregleda bio je utvrditi potencijalno povoljne i štetne učinke primjene metotreksata u pacijenata s PBC-om u odnosu na placebo, drugu intervenciju ili izostanak intervencije, a neovisno o pratećim lijekovima, odnosno kointervencijama ako su one podjednake u obje ispitivane grupe. Uključena su randomizirana klinička istraživanja koja obuhvaćaju pacijente s PBC-om koja je definirana prisutnošću minimalno dvaju od sljedećih kriterija: povišena serumska koncentracija alkalne fosfataze ili drugih markera intrahepatične kolestaze, pozitivan nalaz antimitohondrijskih protutijela (AMA) ili patohistološki nalaz biopsije jetre kompatibilan s PBC-om. Primarni analizirani ishodi obuhvaćaju mortalitet i transplantaciju jetre, dok sekundarne ishode čine svrbež, kronični 
umor, komplikacije kronične jetrene bolesti (krvarenje iz varikoziteta jednjaka, ascites, hepatalna encefalopatija, žutica ili hepatorenalni sindrom), biokemijski jetreni nalazi (alkalna fosfataza, gama-glutamiltransferaza, aspartat aminotransferaza, alanin aminotransferaza, albumin, ukupni kolesterol, imunoglobulini), nalaz biopsije jetre, kvaliteta života i nuspojave liječenja. Pretraga literature rezultirala je s ukupno 574 identificirane reference, a u definitivnu analizu uključeno je pet studija s ukupno 455 ispitanika. Od navedenih pet studija, četiri su uspoređivale metotreksat s placebom, a jedna s kolhicinom. Rezultati su ukazali da metotreksat nema značajnog utjecaja na mortalitet ovih pacijenata, kao ni na potrebu, odnosno učestale transplantacije jetre (slika 4).

Metaanaliza je pokazala da je u usporedbi s placebom metotreksat značajno smanjio pruritus (MD -0,17; $95 \% \mathrm{Cl}-0,25$ do -0,09), jednako kao i u usporedbi s kolhicinom (MD -0,68; $95 \% \mathrm{Cl}$ $-1,11$ do $-0,25)$. Također, u usporedbi s kolhicinom utvrđeno je značajno smanjenje razine alkalne fosfataze (MD -0,41; $95 \% \mathrm{Cl}-0,70$ do $-0,12$ ) i imunoglobulina (MD -0,47; $95 \% \mathrm{Cl}-0,74$ do $-0,20)$, ali navedeni se rezultati temelje na samo jednoj studiji. Kod primjene metotreksata u odnosu na placebo rezultati su pokazali značajno pogoršanje protrombinskog vremena, odnosno koagulopatije (MD 1,60; $95 \% \mathrm{Cl} 1,18$ do 2,02). Nije utvrđen značajni utjecaj metotreksata na druge definirane ishode, a potrebno je naglasiti da su svi rezultati, kao i zaključci, temeljeni na malom broju uključenih studija i randomiziranih pacijenata te kao takvi trebaju biti kritički sagledani. Ovim rezultatima ustanovljeno je da metotreksat nema jasnu ulogu u liječenju pacijenata $\mathrm{s}$ PBC-om te danas i nije dio terapijskog algoritma. Vrlo zanimljiv i prilično citiran sustavni pregled odnosi se na primjenu lijeka bezafibrat u liječenju PBC-a. Bezafibrat je lijek koji se koristi u liječenju hipertrigliceridemije i kombinirane hiperlipidemije. Utvrđeno je da bezafibrat također smanjuje serumsku razinu kolestatskih enzima u asimptomatičnih pacijenata s PBC-om. Točan mehanizam djelovanja nije poznat, ali pretpostavlja se da učinak ostvaruje posredstvom MDR-2 gena (engl. multiple drug-resistant 2 gene) i PPAR- $\alpha$ receptora (engl. peroxisome proliferative-activated receptor alpha). Navedenim putem bezafibrat utječe na imunološki sustav i regulira razinu leu-

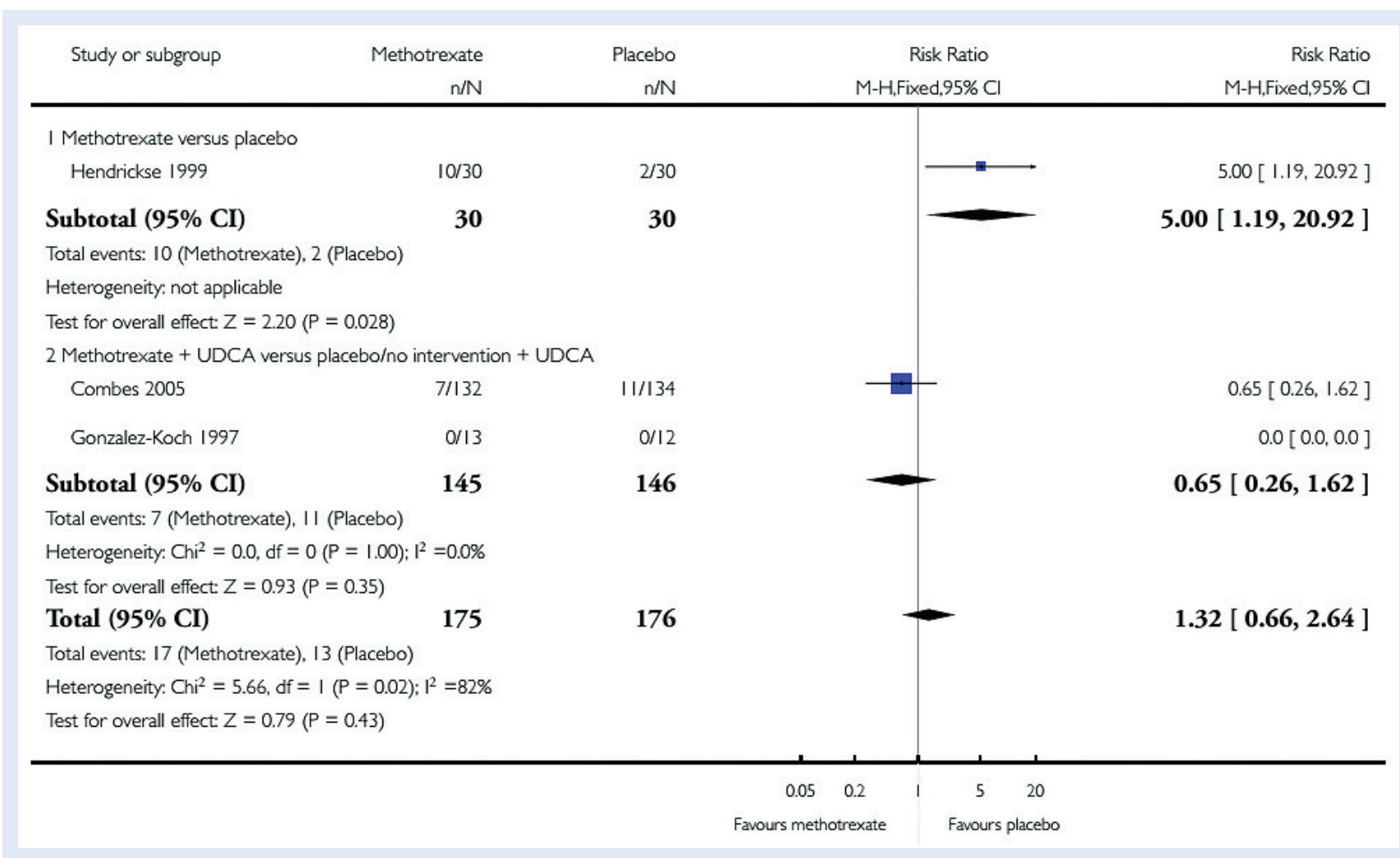

Slika 4. Usporedba metotreksata i placeba u pacijenata s PBC-om. Ishod: mortalitet (preuzeto uz dopuštenje iz ref. 8) 
kotriena B4 te time poboljšava ravnotežu serumske koncentracije lipida. Bezafibrat kontrolira razinu bilijarnih fosfolipida i žučnih kiselina i tako prevenira oštećenje kolangiocita. Dodatno smanjuje razinu perifernih Fas-antigen pozitivnih limfocita $T$ i suprimira imunološki odgovor $u$ pacijenata s PBC-om. Od 95 identificiranih publikacija, ovaj sustavni pregled obuhvatio je šest randomiziranih kliničkih istraživanja s ukupno 151 ispitanikom u konačnu metaanalizu.

$U$ četiri studije bezafibrat u kombinaciji s UDCAom uspoređivan je s monoterapijom UDCA-a, dok je u dvije studije monoterapija befafibratom uspoređivana s monoterapijom UDCA-a, kao standardom liječenja. Analizirani ishodi obuhvaćali su smrtnost i morbiditet povezan s jetrom (žutica, krvarenje iz gornjeg dijela probavnog sustava, ascites, hepatalna encefalopatija, hepatorenalni sindrom), nuspojave i kvalitetu života kao primarne ishode, dok su pruritus, kronični umor, biokemijske analize, histološka analiza biopsije jetre i broj pacijenata koji su prekinuli primjenu bezafibrata zbog nuspojava analizirani kao sekundarni ishodi. U obje usporedbe utvrđeno je da bezafibrat značajno smanjuje serumsku aktivnost alkalne fosfataze, u kombinaciji s UDCA-om (MD -186,04; 95 \% Cl -249,03 do -123,04) i kao monoterapija (MD -162,90; $95 \% \mathrm{Cl}-199,68$ do $-126,12)$. Navedeno je potvrđeno i sekvencijskom analizom studija. No, osnovna činjenica je da temeljem rezultata metaanalize nije potvrđen ikakav značajan učinak bezafibrata na klinički važne ishode te, unatoč povoljnom učinku na biokemijske parametre, nema dokaza da navedeni učinak rezultira poboljšanjem kliničkog tijeka pacijenata, smanjenjem komplikacija i redukcijom mortaliteta.

U trećem sustavnom pregledu uklopljenom u tematiku primarne bilijarne ciroze analizirana je primjena hormonske nadomjesne terapije za liječenje osteoporoze $u$ žena oboljelih od primarne bilijarne ciroze, kao jedne od njenih učestalijih komplikacija. Sustavnom pretragom literature utvrđena su isključivo dva randomizirana klinička istraživanja s ukupno 49 ispitanika. Prema dostupnim informacijama nema dovoljno dokaza da primjena hormonske nadomjesne terapije u pacijentica S PBC-om značajno utječe na smanjenje smrtnosti i učestalost patoloških prijeloma, ali je utvrđeno značajno poboljšanje koštane gustoće detektirane denzitometrijom u predjelu proksimalnog femura (MD 2,24 g/cm²; $95 \% \mathrm{Cl} \mathrm{0,74} \mathrm{do}$ $3,74)$. Gustoća kosti u predjelu lumbalne kralježnice, međutim, nije bila značajno promijenjena primjenom hormonske nadomjesne terapije. Unatoč vrlo ograničenim dokazima za bilo kakvu učinkovitost navedene terapiju u pacijentica $s$ PBC-om, utvrđeno je da značajno veći broj ispitanika prekida navedenu terapiju zbog nuspojava (RR 5,26; $95 \% \mathrm{Cl}$ 1,26 do 22,04).

\section{Primarni sklerozirajući kolangitis ${ }^{11,12}$}

Naša je skupina autora objavila dva Cochrane sustavna pregleda na temu primarnog sklerozirajućeg kolangitisa. U prvom je analizirana primjena glukokortikoida, dok su u drugom obuhvaćene studije primjene žučnih kiselina kao terapijske opcije.

Glukokortikoidi su često primjenjivani lijekovi za brojne indikacije, koji imaju protuupalno djelovanje te su pojedine studije pokazale njihov potencijalno dobrobitni učinak u liječenju ovih pacijenata. Međutim, njihova dugotrajna primjena također se povezuje s razvojem brojnih nuspojava od kojih su mnoge klinički relevantne, a neke potencijalno i po život opasne. Pretraga je inicijalno rezultirala s 638 referenci, od kojih su kriterije uključivanja zadovoljavale samo dvije studije. U obje su uspoređivane različite intervencije, odnosno bilijarna lavaža s fiziološkom otopoinom hidrokortizona i bilijarna lavaža isključivo fiziološkom otopinom te oralni budezonid s prednizonom. Zbog karakteristika studija nije bilo moguće provesti metaanalizu te se rezultati sustavnog pregleda oslanjanju na same rezultate pojedinih studija. Ovime je zapravo utvrđeno da nema postojećih i dostupnih adekvatnih dokaza kojima bi se potkrijepila primjena glukokortikoida u PSC-u. Žučne kiseline predstavljaju standard medikamentoznog liječenja kroničnih kolestatskih bolesti jetre. Najčešće primjenjivana je ursodeoksikolna kiselina (UDCA). Žučne kiseline općenito se dijele na hidrofobne, poput endogenih deokiskolne i kenodeoksikolne kiseline, koje se u slučaju razvoja kolestaze akumuliraju u žučnim vodovima i djeluju toksično oštećujući stanične membrane kolangiocita i hepatocita. Dodatkom UDCA povećava se 


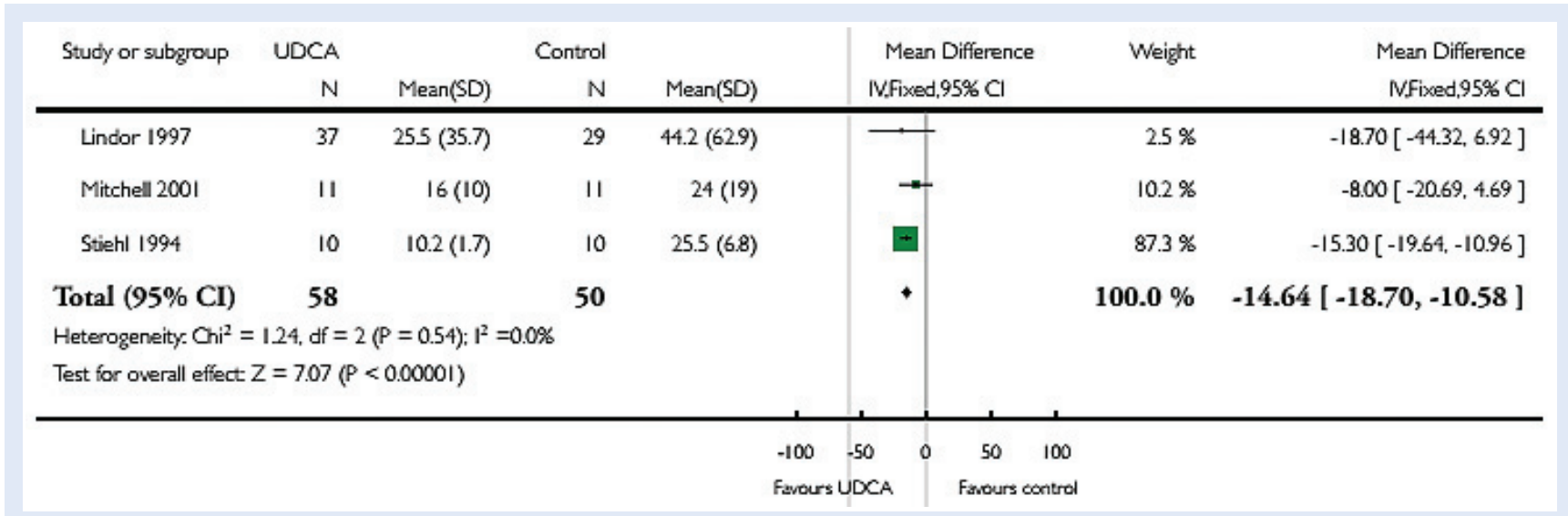

Slika 5. Usporedba učinka primjene UDCA-a u odnosu na kontrolu (placebo ili izostanak intervencije) na serumsku koncentraciju ukupnog bilirubina ( $\mu \mathrm{mol} / \mathrm{L}$ ) na kraju liječenja (preuzeto uz dopuštenje iz ref. 12)

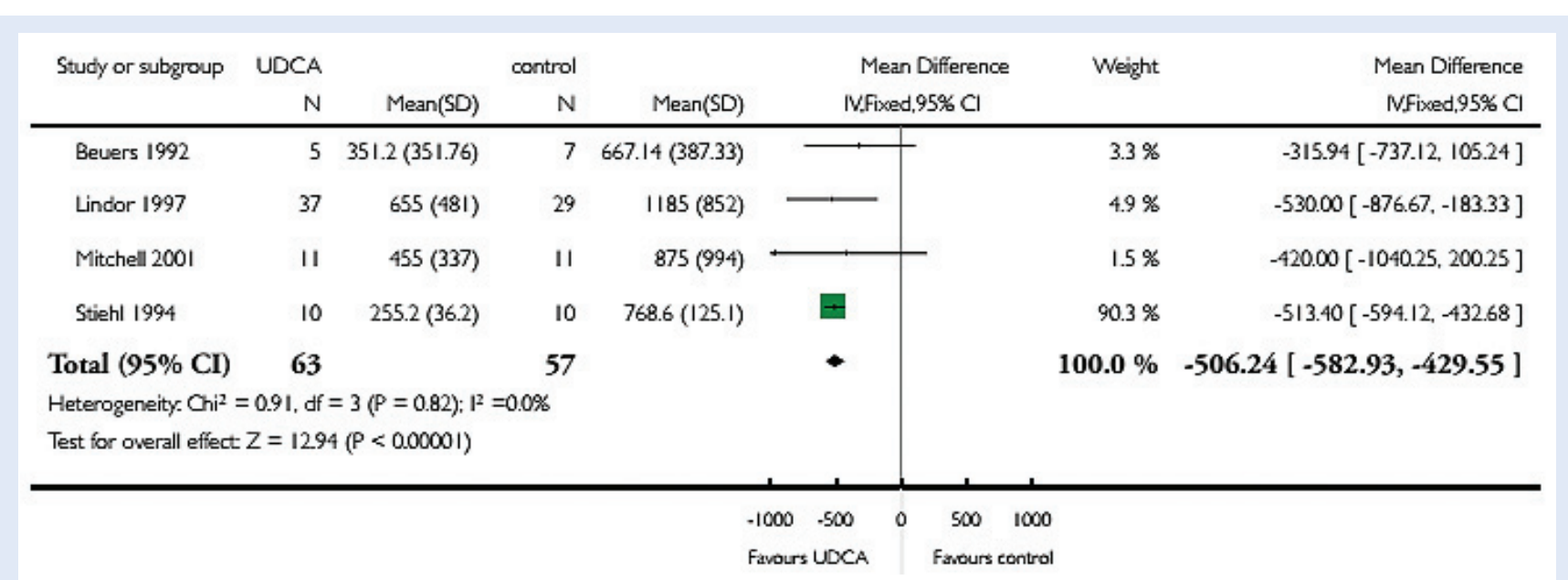

Slika 6. Usporedba učinka primjene UDCA-a u odnosu na kontrolu (placebo ili izostanak intervencije) na serumsku aktivnost alkalne fosfataze (IU/L) na kraju liječenja (preuzeto uz dopuštenje iz ref. 12)

udio hidrofilnih kiselina, koje djeluju protektivno stabilizirajući stanične membrane. Dodatno se smanjuje apsorpcija toksičnih endogenih žučnih kiselina $u$ terminalnom ileumu te UDCA ispoljava $\mathrm{i}$ imunomodulatorno djelovanje inhibicijom abnormalnih molekula klase I glavnog sustava histokompatibilnosti. $U$ metaanalizu je uključeno ukupno 8 studija s 592 ispitanika. U svim je uključenim studijama ispitivan UDCA, pri čemu je u sedam studija uspoređivan s placebom, a u jednoj s pristupom bez ikakve intervencije. Medijan duljine primjene lijeka iznosio je tri godine s rasponom od tri mjeseca do šest godina. Primjena UDCA-a nije značajnije utjecala na smanjenje smrtnosti u pacijenata $\mathrm{s}$ PSC-om (RR 1,00; $95 \%$ 0,46 do 2,20). Pacijenti su uglavnom dobro podnosili primjenu UDCA-a te nije bilo značajnije razlike u prekidu terapije i nuspojavama, a najčešća prijavljivana nuspojava bile su proljevaste stolice i to uglavnom blažeg kliničkog tijeka. Kvaliteta života prikazana je isključivo u jednoj uključenoj studiji te za navedeni ishod nije bilo moguće provesti metaanalizu. U sklopu sekundarnih ishoda sustavnog pregleda analiziran je utjecaj UDCA-a na serumsku razinu bilirubina te je utvrđeno njeno značajno smanjenje (slika 5), kao i značajno smanjenje vrijednosti alkalne fosfataze (ALP) (slika 6). Učinak UDCA očitovao se i značajnom redukcijom serumske aktivnosti AST (MD -46 IU/L; $95 \% \mathrm{Cl}-77$ do -16) i GGT (MD -260 IU/L; $95 \% \mathrm{Cl}-315$ do -205). Među dodatnim sekundarnim ishodima, utvrđeno je da UDCA nema značajni utjecaj na serumsku koncentraciju albumina, pogoršanje histološke slike jetre i kolangiografski nalaz.

lako primjena UDCA-a predstavlja standard liječenja kroničnih kolestatskih bolesti jetre, uključujući 
PSC, rezultatima našeg sustavnog pregleda nismo utvrdili značajnu razinu dokaza kojima bismo potkrijepili povoljan učinak UDCA-a na klinički relevantne ishode $u$ ovih pacijenata. Potrebna su dodatna adekvatnog dizajnirana randomizirana istraživanja odgovarajuće snage kojima bi se eventualno promijenili postojeći rezultati i naše znanje u učincima UDCA-a u PSC-u.

\section{DIJAGNOSTIČKE METODE ZA DETEKCIJU} KOLEDOKOLITIJAZE ${ }^{13-15}$

Dijagnostički sustavni pregledi Cochrane predstavljaju relativno nov oblik istraživanja u sklopu Cochrane kolaboracije. Počeli su se razvijati tijekom posljednjih nekoliko godina, upravo predvođeni hepatobilijarnom grupom Cochrane. Riječka je grupa autora uključena u izradu serije od tri dijagnostička sustavna pregleda koji čine cjelinu istraživanja dijagnostičke metodologije u detekciji koledokolitijaze. U prvom istraživanju uspoređivani su transabdominalni ultrazvuk abdomena (UZ) i serumski biokemijski testovi, potom endoskopski ultrazvuk (EUZ) i magnetna rezonantna kolangiopankreatografija (MRCP) te endoskopska retrogradna kolangiopankreatografija (ERCP) i intraoperativna kolangiografija (IOC). Uključene su samo studije u kojima je izražen broj stvarno pozitivnih i stvarno negativnih te lažno pozitivnih i laž- no negativnih nalaza za navedene metode, a nalazi su potvrđeni endoskopskom ili kirurškom ekstrakcijom konkremenata iz glavnog žučnog voda.

U sustavnom pregledu usporedbe UZ-a i serumskih biokemijskih testova, točnije serumske koncentracije ukupnog bilirubina i alkalne fosfataze, uključeno je pet studija s 523 ispitanika koje evaluiraju dijagnostičku točnost UZ-a i jedna studija $s$ 262 ispitanika koja uspoređuje UZ, bilirubin i ALP. U prvoj skupini studija rezultati ukazuju da je osjetljivost UZ-a za detekciju koledokolitijaze 0,73 (95\% Cl 0,44 do 0,90), dok je specifičnost 0,91 (95\% Cl 0,84 do 0,95). Posttestna vjerojatnost detekcije koledokolitijaze s pozitivnim nalazom UZ-a bila je 0,85 (95\% Cl 0,75 do 0,91), a s negativnim nalazom 0,17 (95\% Cl 0,08 do 0,33). U preostaloj studiji osjetljivost UZ-a iznosila je 0,32 (95\% Cl 0,15 do 0,54), a specifičnost 0,95 (95\% $\mathrm{Cl} 0,91$ do 0,97). Za vrijednosti bilirubina $>22,23$ $\mu \mathrm{mol} / \mathrm{L}$ utvrđene su osjetljivost od 0,84 (95\% Cl $0,64$ do 0,95$)$ i specifičnost od 0,91 (95\% Cl 0,86 do 0,94), dok su za vrijednosti ALP > $125 \mathrm{IU} / \mathrm{L}$ utvrđene osjetljivost od 0,92 (95\% Cl 0,74 do $0,99)$ i specifičnost od 0,79 (95 \% Cl 0,74 do 0,84). Navedeni rezultati upućivali su da bi mnogi pacijenti s negativnim nalazima UZ-a i laboratorijskih testova mogli imati koledokolitijazu te je daljnje dijagnostičko testiranje drugim metodama indici-

Tablica 2. Sažetak rezultata primjene EUZ-a i MRCP-a u detekciji koledokolitijaze pri najnižoj i najvišoj predtestnoj vjerojatnosti (prilagođeno prema ref. 14)

\begin{tabular}{|c|c|c|c|c|c|}
\hline $\begin{array}{l}\text { Predtestna } \\
\text { vjerojatnost }\end{array}$ & Test & $\begin{array}{l}\text { Ukupna osjetljivost } \\
\qquad(95 \% \mathrm{Cl})\end{array}$ & $\begin{array}{l}\text { Ukupna specifičnost } \\
\qquad(95 \% \mathrm{Cl})\end{array}$ & $\begin{array}{l}\text { Pozitivna posttestna } \\
\text { vjerojatnost } \\
(95 \% \mathrm{Cl})\end{array}$ & $\begin{array}{l}\text { Negativna posttestna } \\
\text { vjerojatnost } \\
(95 \% \mathrm{Cl})\end{array}$ \\
\hline \multirow{2}{*}{0,14} & EUZ & $0,95(0,91$ do 0,97$)$ & $0,97(0,94$ do 0,99$)$ & $0,85(0,72$ do 0,93$)$ & $0,01(0,01$ do 0,02$)$ \\
\hline & MRCP & $0,93(0,87$ do 0,96$)$ & $0,96(0,89$ do 0,98$)$ & $0,79(0,61$ do 0,90$)$ & $0,01(0,01$ do 0,02$)$ \\
\hline \multirow{2}{*}{0,68} & EUZ & $0,95(0,91$ do 0,97$)$ & $0,97(0,94$ do 0,99$)$ & $0,99(0,97$ do 0,99$)$ & $0,10(0,06$ do 0,16$)$ \\
\hline & MRCP & $0,93(0,87$ do 0,96$)$ & $0,96(0,89$ do 0,98$)$ & $0,98(0,95$ do 0,99$)$ & $0,13(0,08$ do 0,23$)$ \\
\hline
\end{tabular}

Tablica 3. Sažetak rezultata primjene ERCP-a i IOC-a u detekciji koledokolitijaze pri najnižoj i najvišoj predtestnoj vjerojatnosti (prilagođeno prema ref. 15)

\begin{tabular}{|c|c|c|c|c|c|}
\hline $\begin{array}{c}\text { Predtestna } \\
\text { vjerojatnost }\end{array}$ & Test & $\begin{array}{c}\text { Ukupna osjetljivost } \\
(\mathbf{9 5} \% \mathbf{C l})\end{array}$ & $\begin{array}{c}\text { Ukupna specifičnost } \\
(\mathbf{9 5} \% \mathbf{C l})\end{array}$ & $\begin{array}{c}\text { Pozitivna posttestna } \\
\text { vjerojatnost } \\
(\mathbf{9 5} \% \mathbf{C l})\end{array}$ & $\begin{array}{c}\text { Negativna posttestna } \\
\text { vjerojatnost } \\
(\mathbf{9 5} \% \mathrm{Cl})\end{array}$ \\
\hline \multirow{2}{*}{0,12} & ERCP & $0,83(0,72$ do 0,90$)$ & $0,99(0,94$ do 1,00$)$ & $0,90(0,66$ do 0,98$)$ & $0,02(0,01$ do 0,04$)$ \\
\hline \multirow{2}{*}{0,68} & IOC & $0,99(0,83$ do 1,00$)$ & $0,99(0,95$ do 1,00$)$ & $0,94(0,60$ do 0,99$)$ & $0,00(0,00$ do 0,03$)$ \\
\hline & ERCP & $0,83(0,72$ do 0,90$)$ & $0,99(0,94$ do 1,00$)$ & $0,99(0,97$ do 1,00$)$ & $0,28(0,18$ do 0,39$)$ \\
\cline { 2 - 7 } & IOC & $0,99(0,83$ do 1,00$)$ & $0,99(0,95$ do 1,00$)$ & $1,00(0,96$ do 1,00$)$ & $0,02(0,00$ do 0,30$)$ \\
\hline
\end{tabular}


rano. Mogućnost lažno pozitivnih rezultata je manja, ali u slučaju neodgovarajuće kliničke slike koledokolitijaze indicirana je dodatna dijagnostika. EUZ i MRCP predstavljaju najznačajnije dijagnostičke metode detekcije koledokolitijaze današnjice. Nakon standardnog transabdominalnog UZ-a i određivanja bilirubina te kolestatskih enzima, jedna od ovih dviju metoda predstavlja najčešći drugi korak u dijagnostičkom postupku. U pravilu se oba testa ne provode zajedno, jer se pozitivni ili negativni rezultati koriste za donošenje definitivne kliničke odluke, odnosno terapijskog odabira. Uključeno je 18 studija s 2366 ispitanika. U 11 studija evaluiran je EUZ, dok je u pet studija evaIuiran MRCP. Dvije studije istraživale su obje dijagnostičke metode. Rezultati skupne osjetljivosti i specifičnosti, kao i ostalih parametara, prikazani su u tablici 2.

Temeljem rezultata moglo se zaključiti da EUZ i MRCP imaju visoku dijagnostičku točnost $u$ detekciji koledokolitijaze. U slučaju pozitivnog nalaza bilo koje od navedenih metoda indicirano je terapijsko djelovanje, odnosno ekstrakcija konkremenata, dok u slučaju negativnog nalaza daljnje dijagnostičko-terapijsko postupanje nije potrebno, osim u slučaju persistiranja simptomatologije. Odabir metode definiran je prije svega dostupnošću i kontraindikacijama.

$U$ posljednjem sustavnom pregledu ove serije uspoređivana je primjena ERCP-a i intraoperativne kolangiografije u detekcije koledokolitijaze. U današnjoj praksi ERCP nije indiciran kao dijagnostička metoda zbog potencijalno klinički značajnih komplikacija, poput akutnog pankreatitisa, te se koristi prvenstveno u terapijske svrhe. Zbog dostupnosti i pouzdanosti ranije spomenutih dijagnostičkih pretraga, važnost IOC-a također je značajno umanjena. S ciljem utvrđivanja dijagnostičke točnosti ovih metoda provedena je sustavna pretraga većeg broja baza podataka, koja je rezultirala s ukupno pet uključenih studija s 318 randomiziranih pacijenata, koje su evaluirale ERCP i pet studija s 654 pacijenta koje su evaluirale IOC. Karakteristike dijagnostičkih performansi koje su rezultirale analizom navedenih studija za ERCP i IOC prikazane su u tablici 3.

lako se prema dostupnim rezultatima može činiti da IOC ima bolju osjetljivost od ERCP-a, potrebno je naglasiti da niti jedna od uključenih studija nije međusobno uspoređivala ove dvije metode. Pouzdanost u detekciji koledokolitijaze je značajna, kao što su uglavnom pouzdane i odluke o terapijskoj intervenciji temeljem navedene dijagnostike. Postoji manji postotak ljudi koji mogu imati kamence zajedničkog žučnog voda unatoč negativnim rezultatima ovih testova i u tih je pacijenata indicirano resetiranje ako je klinička sumnja na koledokolitijazu visoka.

\section{ENTERALNA PREHRANA U PACIJENATA} S AKUTNIM PANKREATITISOM ${ }^{16}$

Akutni pankreatitis (AP) predstavlja jednu od najčešćih i potencijalno fatalnih bolesti u gastroenterologiji. Ova upalna bolest gušterače najčešće je uzrokovana žučnim kamencima i ekscesivnom konzumacijom alkohola. Unatoč napretku na području dijagnostike i liječenja, ishodi ove bolesti nisu se bitnije promijenili tijekom posljednjih nekoliko desetljeća. U kontekstu nutritivnog pristupa liječenju AP-a, enteralna prehrana (EP) dokazano je učinkovitija od primjene totalne parenteralne prehrane $u$ redukciji organskog zatajenja, infektivnih komplikacija i smrtnosti. Do sada je veći broj randomiziranih kliničkih istraživanja i metaanaliza objavljeno na temu usporedbe enteralne i parenteralne prehrane $u A P-u$, ali je ovaj Cochrane sustavni pregled prvi put prikazao primjenu i učinkovitost specifičnih vrsta formulacija enteralne prehrane. EP obuhvaća više formula, koje se u osnovi mogu podijeliti na elementarne, polimerne i specifične. Ove posljednje obuhvaćaju različite modifikacije, poput imunonutricije obogaćene glutaminom, argininom, omega-3 masnim kiselinama i sl., potom EP-e obogaćene probioticima, prebioticima, vlaknima te formule specifično dizajnirane za određene bolesti itd.

Sustavnom pretragom literature obuhvaćeno je pet različitih baza podataka, Medline, Embase, Science Citation Index-Expanded, The Cochrane Upper Gastrointestinal and Pancreatic Diseases Group Specialised Register of Clinical Trials i Cochrane Central Register of Controlled Trials (CENTRAL).

Sukladno uključnim kriterijima obuhvaćena su randomizirana klinička istraživanja neovisno o publikacijskom statusu, jeziku ili zasljepljivanju 


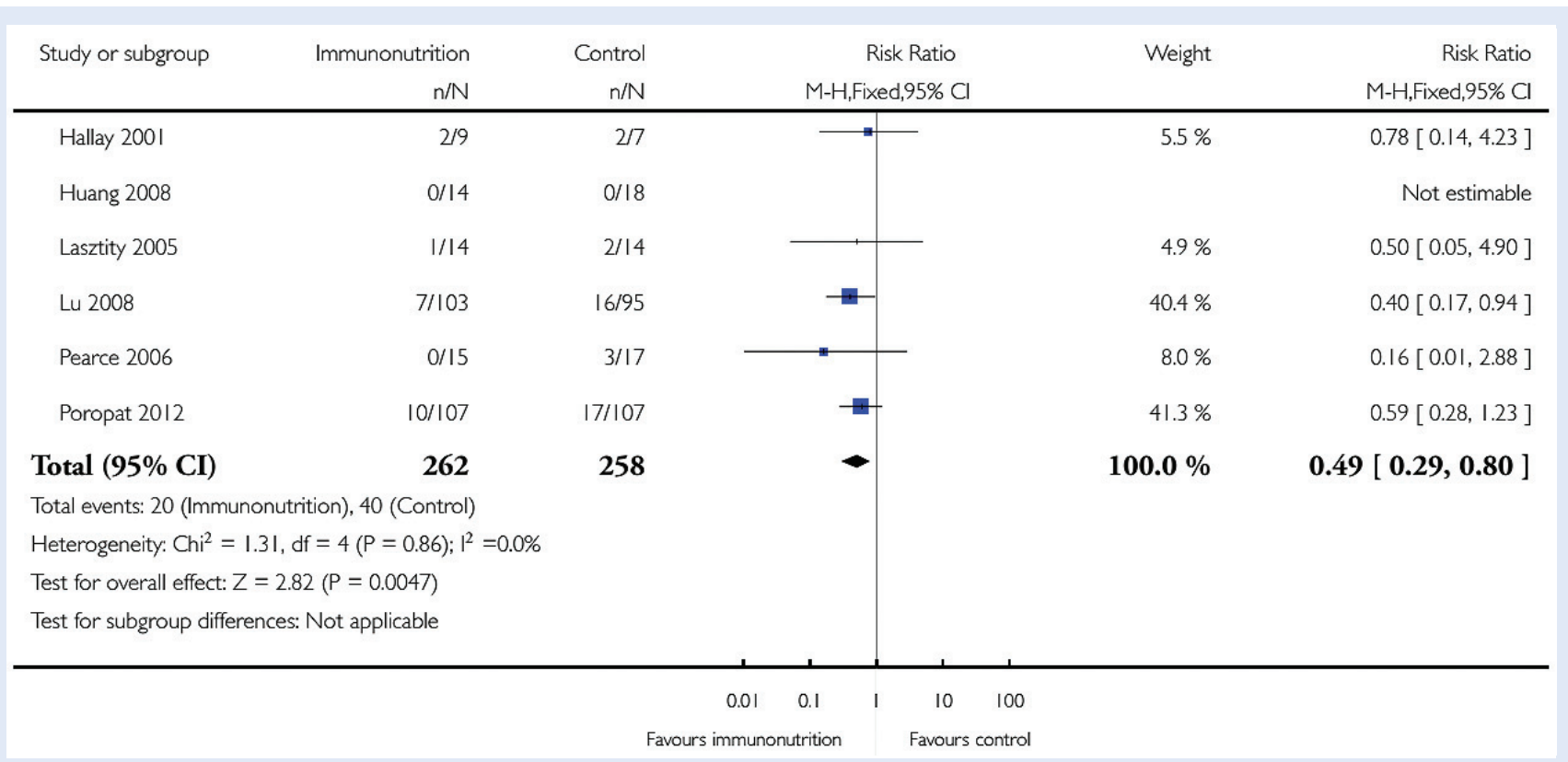

Slika 7. Usporedba primjene imunonutricije u odnosu na kontrolu (druga formula enteralne prehrane, placebo ili izostanak intervencije). Ishod: sveukupna smrtnost (preuzeto uz dopuštenje iz ref. 16)

koja istražuju primjenu bilo koje formulacije EP-a u usporedbi s drugim oblikom EP-a, placebom ili izostankom intervencije u liječenju pacijenata $s$ AP-om. Primarni ishodi obuhvaćaju ukupnu smrtnost, sindrom sustavnog upalnog odgovora, sindrom višestrukog organskog zatajenja i nuspojave. U sekundarne ishode uključeni su: lokalne septične komplikacije (inficirana nekroza, apsces gušterače), ostale lokalne komplikacije (sterilna nekroza, tekuće kolekcije, pseudocista, fistula), ostale infektivne komplikacije (pneumonija, infekcija urinarnog sustava, septikemija), duIjina hospitalizacije i kvaliteta života.

U metaanalizu uključeno je ukupno 15 studija $\mathrm{s}$ ukupno 1376 ispitanika. Utvrđeno je da primjena imunonutricije značajno smanjuje smrtnost u odnosu na kontrolu (slika 7), ali bez utvrđenog značajnog učinka na ostale ishode. Prilikom analize studija s EP-om i dodatkom probiotika utvrđena je izrazita heterogenost rezultata, kao posljedica jedne uključene studije s gotovo oprečnim rezultatima, u kojima je utvrđen značajno veći broj umrlih kao posljedica organskog zatajenja u grupi liječenoj probioticima ${ }^{17}$. Utvrđeno je da navedena studija sadrži značajne metodološke pogreške te su rezultati posljedica važne sustavne pogreške. Ukupni rezultat metaanalize nije pokazao značajan utjecaj EP-a s probioticima na analizirane ishode. Kako bi se utvrdila važnost navedene heterogenosti i spomenute studije, provedena je post-hoc analiza osjetljivosti u kojoj je iz metaanalize navedena studija isključena. Rezultati analize osjetljivosti ukazali su da u tom slučaju EP obogaćen probioticima značajno smanjuje smrtnost (RR 0,30; $95 \% \mathrm{Cl} 0,10$ do 0,84), organsko zatajenje (RR 0,74; $95 \% \mathrm{Cl} 0,59$ do 0,92) i lokalne septične komplikacije (RR 0,40; $95 \% \mathrm{Cl} 0,22$ do $0,72)$. Analizom ostalih formulacija enteralne prehrane nije utvrđen značajan utjecaj na ishode u akutnom pankreatitisu, ali važno je naglasiti da su navedene analize provedene na malom broju studija, odnosno ispitanika.

Rezultati su pokazali da je primjena imunonutricije sigurna i potencijalno učinkovita u liječenju pacijenata s AP-om te potencijalno pozitivno utječe na klinički relevantne ishode. S obzirom na to da su navedeni rezultati bazirani na i dalje relativno malom broju uključenih pacijenata, preporučuje se daljnji nastavak istraživanja navedene teme. Primjena probiotika je potencijalno neopravdano kontraindicirana u današnjem terapijskom pristupu te su rezultati osnovne i post-hoc analize utvrdili da je navedena percepcija posljedica sustavne pogreške i dodatna istraživanja pomogla bi u rasvjetljavanju i utvrđivanju istinske uloge probiotika u liječenju AP-a. 


\section{ZAKLJUČAK}

Uključenost u rad Cochrane kolaboracije omogućava sudjelovanje u produkciji znanstvenih radova najviše metodološke razine. Osim izučavanja znanstvene metodologije, Cochrane kolaboracija omogućava upoznavanje, suradnju i zajednički rad s nekim od najvećih stručnjaka s područja znanstvene metodologije, biostatistike, ali i specifičnih medicinskih područja. Izrada Cochrane sustavnih pregleda potječe od autora, orijentirana je i usmjerena na autore i istovremeno podložna kritičkoj recenziji međunarodnih stručnjaka i javnosti općenito. Uz neosporivo znanje koje je usvojeno ovim doprinosom riječke Cochrane grupe, te spoznaje i stručne dokaze koji su dosegnuti u specifičnim područjima gastroenterologije, rad u Cochrane kolaboraciji rezultirao je i dvjema doktorskim disertacijama temeljenim na Cochrane sustavnim pregledima, prvim u našoj zemlji. Publicirani sustavni pregledi nerijetko su citirani u nekim od najrelevantnijih gastroenteroloških časopisa, a koriste se i kao reference u donošenju smjernica i stručnih preporuka, kao primjerice smjernice za dijagnostiku i liječenje koledokolitijaze te preporuke nutritivnog pristupa liječenju akutnog pankreatitisa ${ }^{18,19}$. Usvojeno znanje omogućilo je i sada već sustavno održavanje tečajeva medicine temeljene na dokazima za studente poslijediplomskih studija s ciljem podizanja svijesti i razine edukacije o važnosti adekvatnog razumijevanja znanstvene metodologije, znanstveno-istraživačkog rada i posljedično stručno djelovanja koje se temelji na čvrstim dokazima.

Izjava o sukobu interesa: autori izjavljuju da ne postoji sukob interesa.

\section{LITERATURA}

1. Messina JP, Humphreys I, Flaxman A, Brown A, Cooke GS, Pybus OG et al. Global distribution and prevalence of hepatitis C virus genotypes. Hepatology 2015;61: 77-87.

2. Poropat G, Milic S, Stimac D. Suvremeni pristup liječenju kroničnog hepatitisa C. Medicina Fluminensis 2016;52:4-13.

3. Fried MW, Shiffman ML, Reddy KR, Smith C, Marinos G, Goncales FL, Jr. et al. Peginterferon alfa-2a plus ribavirin for chronic hepatitis $C$ virus infection. N Engl J Med 2002;347:975-82.
4. Manns MP, McHutchison JG, Gordon SC, Rustgi VK, Shiffman $M$, Reindollar $R$ et al. Peginterferon alfa-2b plus ribavirin compared with interferon alfa- 2 b plus ribavirin for initial treatment of chronic hepatitis C: a randomised trial. Lancet 2001;358:958-65.

5. Hauser G, Awad T, Brok J, Thorlund K, Stimac D, Mabrouk $M$ et al. Peginterferon plus ribavirin versus interferon plus ribavirin for chronic hepatitis C. Cochrane Database Syst Rev 2014;2:CD005441.

6. Hauser G, Awad T, Thorlund K, Stimac D, Mabrouk M, Gluud C. Peginterferon alpha-2a versus peginterferon alpha-2b for chronic hepatitis C. Cochrane Database Syst Rev 2014;2:CD005642.

7. Jakobsen JC NE, Feinberg J, Katakam KK, Fobian K, Hauser G, Poropat Get al. Direct-acting antivirals for chronic hepatitis C. Cochrane Database of Systematic Reviews 2017;6:CD012143.

8. Giljaca V, Poropat G, Stimac D, Gluud C. Methotrexate for primary biliary cirrhosis. Cochrane Database Syst Rev 2010;5:CD004385.

9. Rudic JS, Poropat G, Krstic MN, Bjelakovic G, Gluud C. Bezafibrate for primary biliary cirrhosis. Cochrane Database Syst Rev 2012;1:CD009145.

10. Rudic JS, Poropat G, Krstic MN, Bjelakovic G, Gluud C. Hormone replacement for osteoporosis in women with primary biliary cirrhosis. Cochrane Database Syst Rev 2011;12:CD009146.

11. Giljaca V, Poropat G, Stimac D, Gluud C. Glucocorticosteroids for primary sclerosing cholangitis. Cochrane Database Syst Rev 2010;1:CD004036.

12. Poropat G, Giljaca V, Stimac D, Gluud C. Bile acids for primary sclerosing cholangitis. Cochrane Database Syst Rev 2011;1:CD003626.

13. Gurusamy KS, Giljaca V, Takwoingi Y, Higgie D, Poropat $G$, Stimac $D$ et al. Ultrasound versus liver function tests for diagnosis of common bile duct stones. Cochrane Database Syst Rev 2015;2:CD011548.

14. Giljaca V, Gurusamy KS, Takwoingi Y, Higgie D, Poropat $G$, Stimac D et al. Endoscopic ultrasound versus magnetic resonance cholangiopancreatography for common bile duct stones. Cochrane Database Syst Rev 2015;2:CD011549.

15. Gurusamy KS, Giljaca V, Takwoingi Y, Higgie D, Poropat $G$, Stimac D et al. Endoscopic retrograde cholangiopancreatography versus intraoperative cholangiography for diagnosis of common bile duct stones. Cochrane Database Syst Rev 2015;2:CD010339.

16. Poropat G, Giljaca V, Hauser G, Stimac D. Enteral nutrition formulations for acute pancreatitis. Cochrane Database Syst Rev 2015;3:CD010605.

17. Besselink MG, van Santvoort HC, Buskens E, Boermeester MA, van Goor H, Timmerman HM et al. Probiotic prophylaxis in predicted severe acute pancreatitis: A randomised, double-blind, placebo-controlled trial. Lancet 2008;371:651-9.

18. Williams E, Beckingham I, El Sayed G, Gurusamy K, Sturgess $\mathrm{R}$, Webster $\mathrm{G}$ et al. Updated guideline on the management of common bile duct stones (cbds). Gut 2017;66:765-82.

19. Krishnan K. Nutritional management of acute pancreatitis. Curr Opin Gastroenterol 2017;33:102-6. 